Original Research Paper

\title{
Effect of particle size of starting oxide powders on the performance of doped-lanthanum oxyapatite produced by mechanical alloying followed by microwave sintering
}

\author{
F.A.C. Oliveira ${ }^{a}$, T. Marcelo ${ }^{a}$, C. Alves ${ }^{\text {a }}$, M. Santos ${ }^{\text {b }}$, J. Mascarenhas ${ }^{a}$, B. Trindade ${ }^{\text {b, } *}$ \\ a Laboratório Nacional de Energia e Geologia IP, Estrada do Paço do Lumiar, 1649-038 Lisboa, Portugal \\ b CEMUC, Mechanical Engineering Department, University of Coimbra, Rua Luís Reis Santos, 3030-788 Coimbra, Portugal
}

\section{A R T I C L E I N F O}

\section{Article history:}

Received 29 November 2013

Received in revised form 3 March 2014

Accepted 17 March 2014

Available online 6 April 2014

\section{Keywords:}

Lanthanum oxyapatite

Microwave processing

Microstructure-final

Mechanical properties

\begin{abstract}
A B S T R A C T
$\mathrm{La}_{9.33} \mathrm{Si}_{2} \mathrm{Ge}_{4} \mathrm{O}_{26}$ oxyapatite powders were synthesized at room temperature through mechanical alloying of $\mathrm{La}_{2} \mathrm{O}_{3}, \mathrm{GeO}_{2}$ and $\mathrm{SiO}_{2}$ precursor powders with different particle sizes as well as crystal structure in the case of silica powder (crystalline/amorphous). The mechanical alloyed mixtures were subsequently sintered by microwave heating at $1350^{\circ} \mathrm{C}$ for $1 \mathrm{~h}$ in order to obtain dense and homogeneous materials. All sintered materials consisted of the target apatite phase although minor amounts of secondary phases (e.g. $\mathrm{La}_{4} \mathrm{GeO}_{8}$ ) were also present only in samples obtained from micrometric $\mathrm{SiO}_{2}$ powders with a crystalline structure. The microstructure of the materials obtained from nanometric $\mathrm{SiO}_{2}$ with an amorphous structure was found to be more homogenous than the ones obtained from micrometric/crystalline silica. The mechanical behavior of the samples was slightly dependent on the particle size of the precursors and on the $\mathrm{SiO}_{2}$ crystallinity.

(c) 2014 The Society of Powder Technology Japan. Published by Elsevier B.V. and The Society of Powder
\end{abstract} Technology Japan. All rights reserved.

\section{Introduction}

Current developments on solid oxide fuel cell (SOFC) are aiming at developing mixed (electronic and ionic) conducting electrolytes for low operating temperature $\left(<800^{\circ} \mathrm{C}\right)$ [1]. Amongst potential candidate materials, apatite-type ionic conductors, such as rareearth lanthanide silicates have attracted much interest because of their considerable ionic conductivity, low activation energies and superior transport properties [1,2]. Therefore, new processing routes for these apatite systems are being sought. Indeed, conventional processing of dense $\mathrm{La}_{9.33} \mathrm{Si}_{2} \mathrm{Ge}_{4} \mathrm{O}_{26}$ ceramics requires sintering at elevated temperatures (typically $1600^{\circ} \mathrm{C}$ ) [1]. This raises a key problem of Ge loss especially upon prolonged heating at high temperature $\left(>1350{ }^{\circ} \mathrm{C}\right)$ due to $\mathrm{GeO}_{2}$ volatilization [2]. Ge loss may lead to the formation of secondary phases with different La:Ge ratios, namely $\mathrm{La}_{2} \mathrm{GeO}_{5}$ or $\mathrm{La}_{4} \mathrm{GeO}_{8}$. Therefore, composition of the samples might change at the typical temperature range required to achieve dense materials. As a result, there is a crucial need to lower processing temperatures through alternative synthesis methods and/or sintering techniques. Recently, considerable interest has arisen on the use of microwave (MW) energy to sinter

\footnotetext{
* Corresponding author. Tel.: +351 239790 794; fax: +351 239790701.

E-mail address: bruno.trindade@dem.uc.pt (B. Trindade).
}

ceramic compacts. The particular requirements of sintering ceramic powders make it one of the most challenging applications for MW processing. Apparently being a simple approach, MW sintering is, in fact, a complex process involving the propagation and absorption of electromagnetic waves, heat transport within the material, and densification.

MW processing has been shown to enhance sintering of various technical ceramics, such as alumina [3-5], Y-TZP [6-8], zirconiatoughened alumina [9-11], cordierite [12], aluminum nitride [13] and mullite [14], either by lowering their sintering temperature or shortening sintering times in comparison to conventional processes. This was regarded as an advantageous feature when processing Ge-containing materials. Moreover, in the case of MW absorber materials, MW heating leads to a more uniform firing since the microwaves generate heat within the volume of the part rather than only at the surface, as in the case of conventional radiant heating.

Recently, we successfully obtained dense Ge-doped $\mathrm{La}_{9.33} \mathrm{Si}_{2-}$ $\mathrm{Ge}_{4} \mathrm{O}_{26}$ with apatite-type structure from powders synthesized by mechanical alloying (MA) at room temperature followed by con-

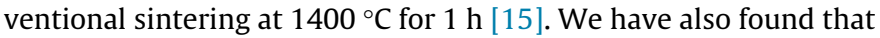
almost fully dense $\mathrm{La}_{9.33} \mathrm{Si}_{2} \mathrm{Ge}_{4} \mathrm{O}_{26}$ pellets could be prepared from MA powder upon MW sintering in the temperature range of $1300-1350{ }^{\circ} \mathrm{C}[16]$. This observation leads us to conclude that 